\title{
Monoline Restrictions, with Applications to Mortgage Insurance and Title Insurance
}

\author{
DWIGHT JAFFEE
}

Haas School of Business, University of California, Berkeley, CA 94720-1900, USA

(E-mail: jaffee@haas.berkeley.edu)

\begin{abstract}
Insurance firms in the United States generally operate on a multiline basis, meaning that they provide coverage for two or more insurance lines, such as auto and homeowner insurance. Most states, however, require that firms offering mortgage or title insurance operate on a monoline basis, meaning that an insurance firm may provide coverage against only one type of risk. This paper investigates the conditions under which monoline restrictions represent efficient regulatory policy. Monoline requirements are an intriguing issue because multiline insurance firms receive the diversification benefit that the firm's capital is available to pay insurance claims on any of its lines. The paper shows, however, that the specific features of the mortgage and title insurance lines create a special case in which monoline restrictions may represent efficient regulatory policy.
\end{abstract}

Key words: Insurance, monoline restriction, mortgage insurance, title insurance.

\section{Introduction}

Monoline insurance firms sell only a single insurance line, while multiline firms sell two or more lines. Most states in the United States (US) impose mandatory monoline restrictions on certain insurance lines, including mortgage, title, and surety insurance. ${ }^{1}$ The primary effect is that a monoline insurer can apply its capital only to pay claims against its single insurance line, while a multiline firm can centralize its capital to pay claims on any of its lines.

The goal of this paper is to investigate the conditions under which monoline restrictions represent effective regulatory policy. This is an intriguing question because a multiline insurance firm receives the diversification benefit that its capital is available to pay claims on any of its lines. Indeed,

${ }^{1}$ Following the 1945 McCarran-Ferguson Act, all US insurance regulation is ceded to the states (Danzon, 1992). Monoline restrictions for mortgage insurance and title insurance are included in the "model codes" developed by the National Association of Insurance Commissioners, on which most state insurance laws are based. 
most insurance lines may be provided on a multiline basis. The mortgage, title, and financial surety lines, however, generally face mandatory monoline restrictions, raising the question whether these lines have special features that warrant the restriction. In this paper, we focus attention specifically on the mortgage insurance and title insurance lines, both because they are quantitatively important and because recent issues in the US and in Australia have raised questions concerning the efficacy of these specific monoline restrictions. ${ }^{2}$

The paper's agenda is: Sections II and III review the mortgage and title insurance industries respectively. Section IV considers the economics of the monoline issue, and applies this analysis to mortgage and title insurance. Section $\mathrm{V}$ provides overall conclusions concerning monoline restrictions and public policy. The basic conclusion of the paper is that the monoline restrictions on both mortgage insurance and title insurance continue to reflect effective regulatory policy.

\section{Mortgage Insurance}

Mortgage insurance provides indemnification against losses created by mortgage defaults that result from falling house prices and the borrower's credit risk. Mortgage insurance is typically purchased by mortgage investors, such as banks, thrift institutions, and government sponsored enterprises (Fannie Mae and Freddie Mac). Mortgage insurers operate under state insurance laws (we use California as an important and typical example). ${ }^{3}$ Most states impose a monoline restriction on mortgage insurers, with the implication that the firm's capital can only be applied against mortgage insurance claims. ${ }^{4}$ In contrast, most casualty insurance lines, such as auto insurance and homeowners insurance, can be integrated within a multiline firm.

${ }^{2}$ In California, the insurance commissioner recently rejected, on monoline grounds, a new title insurance product from Radian Guaranty, Inc (Garamendi, 2003). The Australia insurance regulator recently issued a white paper, Australian Prudential Regulation Authority (2003), to reopen consideration of Australia's monoline restriction.

3 California insurance law refers to "mortgage insurance" and "mortgage guarantee insurance". Our discussion refers directly to California's "mortgage guarantee insurance," but the text uses "mortgage insurance" for brevity. Mortgage insurance should not be confused with mortgage life insurance, which pays off the mortgage if the borrower dies.

${ }^{4}$ The seven US mortgage insurance firms are all monoline. See also Moody's (2003) and Table I below. 


\section{HISTORY OF MORTGAGE INSURANCE IN THE US ${ }^{5}$}

Mortgage insurance industry roots go back to the late 1880s, while the first formal legislation was passed by New York State in 1904. The industry grew rapidly during the real estate boom of the 1920s, but was then entirely bankrupted by the real estate bust of the Great Depression. Conflicts of interest within the mortgage insurance industry exacerbated the industry's Great Depression collapse. The largest conflict was that the mortgage insurers were also acquiring mortgages, then reselling them within insured mortgage pools (an early form of mortgage securitization). As mortgage default rates rose, the insurers fraudulently placed bad loans in insured pools (Graaskamp, 1967). Similar problems at the same time in the business loan market led to the Glass-Steagall Act (forcing the separation of commercial and investment banks).

Real estate markets rapidly recovered following World War II, renewing the need for mortgage insurance. The US federal government had entered the mortgage insurance industry in 1934 with the creation of the Federal Housing Administration (FHA), with the goal of stabilizing real estate markets in the midst of the Great Depression. The Veteran's Administration (VA) program was added after World War II to provide low-cost mortgage guarantees for returning war veterans. Although the government programs expanded rapidly with the post-War boom, there was also demand to recreate a private mortgage insurance industry. However, with memory of the dismal experience of the mortgage insurance industry during the 1930s still strong, state legislatures would not act to recreate a private mortgage insurance industry. In fact, it would be three decades before private mortgage insurance was again offered in the US. (Hereafter, all references to "mortgage insurance" will mean private mortgage insurance, and not the federal programs.)

The breakthrough came when Wisconsin passed a mortgage insurance law in 1956, allowing the chartering of the first post-Depression mortgage insurer, the Mortgage Guaranty Insurance Corporation (MGIC). California followed with a comprehensive mortgage insurance act in 1961, and the California statute became the standard for the mortgage insurance laws that followed in other states (Rapkin, 1973). That standard remains basically in place today, with most variations across the states now eliminated with the adoption of the "model code" written by the National Association of Insurance Commissioners (NAIC). We review the key features below.

\footnotetext{
${ }^{5}$ See Alger (1934), Graaskamp (1967), and Rapkin (1973) for detailed histories of the US mortgage insurance industry, with emphasis on its collapse during the Great Depression of the 1930s.
} 


\section{THE MORTGAGE INSURANCE POLICY}

The standard mortgage insurance policy indemnifies the policy beneficiary (the mortgage investor) against losses created by a covered borrower default, in an amount equal to the first $20-30 \%$ of the lost mortgage principal, depending on the specific coverage chosen. ${ }^{6}$ Mortgage insurance indemnification applies only for losses created by the credit risk of the borrower. That is, the standard policy explicitly excludes all other factors that may also trigger mortgage defaults, such as losses created by fire, earthquakes, floods, hurricanes, and defective titles. To obtain protection against these excluded factors, mortgage lenders generally require borrowers to maintain separate insurance policies against the respective risks.

Mortgage lenders usually require the purchase of mortgage insurance (paid by the borrower) on loans where the initial downpayment is less than the standard $20 \%$ (that is, the loan to value ratio exceeds $80 \%$ ). The insurance premiums are paid by the borrower, usually on a monthly basis at a level contractually set at the outset as a percent of the mortgage balance. If and when the borrower defaults on a mortgage payment, then a foreclosure is initiated and the insurer reimburses the policy beneficiary (the mortgage investor) for the indemnified loss. ${ }^{7}$

A mortgage insurance contract remains in force over the life of the underlying mortgage, or until the policy is cancelled. Mortgage insurance is automatically cancelled when the property is sold or the mortgage refinanced. Also, under the federal Homeowners Protection Act of 1998, the borrower can cancel the policy when the current loan to value ratio falls to $80 \%$, and the insurance firm must cancel the policy if the loan to value ratio falls to $78 \%$.

\section{THE US MORTGAGE INSURANCE INDUSTRY ${ }^{8}$}

The US mortgage insurance industry is concentrated, consisting of just seven holding companies, which in turn own operating subsidiaries licensed in most if not all of the individual states. Holding companies may own monoline subsidiaries, as long as the capital of each monoline subsidiary

\footnotetext{
${ }^{6}$ As the market for low downpayment and subprime mortgages has expanded, private insurers now offer policies that cover more than the traditional $20 \%$ of the mortgage value. In Australia, the standard policy covers $100 \%$ of the loan amount.

7 The mortgage insurer typically has the option to purchase the property for the mortgage principal or to settle the claim for the fixed percentage of the mortgage principal specified in the policy.

8 The Fact Book published by the industry's trade group, Mortgage Insurance Companies of America (2004), is a comprehensive source on the mortgage insurance industry. Moody's (2003) specifies the criteria it applies in rating mortgage insurers, in the process providing an independent description of the industry and its competitive setting.
} 
is sequestered from the holding company and its other subsidiaries. ${ }^{9}$ Mortgage insurers face competition from the federal FHA and VA programs, as well as new securitization methods that transfer the default risk directly to capital market investors. ${ }^{10}$ Dependable demand for mortgage insurance arises from Fannie Mae and Freddie Mac, whose federal charters require that they obtain mortgage insurance or its equivalent on any mortgage loan with an initial loan to value ratio above $80 \%$. Similarly, bank and thrift institution capital regulations provide an incentive for these intermediaries to use mortgage insurance as a credit enhancement.

Table I shows the primary mortgage insurance written during 2004 and the amount of primary insurance in force at year-end 2004 for each of the industry's seven companies. ${ }^{11}$ Insurance written represents the total value

Table I. Primary mortgage insurance written and in force, 2004, by firm

\begin{tabular}{lcccc}
\hline Holding company name & $\begin{array}{l}\text { Insurance } \\
\text { written }\end{array}$ & $\begin{array}{l}\text { Insurance } \\
\text { written }\end{array}$ & $\begin{array}{l}\text { Insurance } \\
\text { in force }\end{array}$ & $\begin{array}{l}\text { Insurance } \\
\text { in force }\end{array}$ \\
\cline { 2 - 5 } & \$ Billion & $\%$ of total & \$ Billion & $\%$ of total \\
\hline Mortgage Guaranty Insurance Corp. & 62.0 & 23.5 & 168.0 & 23.2 \\
PMI Mortgage Insurance Company & 54.7 & 20.7 & 135.8 & 18.7 \\
Radian Guaranty Inc. & 44.6 & 16.9 & 115.3 & 15.9 \\
AIG/United Guaranty Corp. & 33.7 & 12.8 & 97.7 & 13.5 \\
Genworth Financial & 26.7 & 10.1 & 97.9 & 13.5 \\
Republic Mortgage Insurance Co. & 26.3 & 10.0 & 74.8 & 10.3 \\
Triad Guaranty Insurance Corp. & 15.8 & 6.0 & 34.9 & 4.8 \\
Industry total & 263.8 & 100.0 & 724.4 & 100.0 \\
Herfindahl & 1668 & & & \\
\hline
\end{tabular}

Source: Inside Mortgage Finance, February 11, 2005.

9 This insurance law parallels current banking law in the sense that commercial banks are restricted to a narrow "banking business", while their bank holding companies are allowed a much wider range of activities (even investment banking since the repeal of the Glass-Steagall Act).

${ }^{10}$ Mortgage backed securities have long used overcollateralization (mortgage principal exceeding the security principal) as a credit enhancement to attract investors. More recently, so-called 80-10-10 mortgages have been originated in which the borrower contributes a $10 \%$ downpayment and a home equity mortgage is provided for the second $10 \%$, thus eliminating the need for mortgage insurance. The home equity mortgage is then securitized, with the capital market investors in the securitization replacing the mortgage insurer as the holder of the credit risk.

${ }_{11}$ Primary mortgage insurance refers to policies written on individual mortgages, the primary business of the industry. In recent years, mortgage insurers have also started to provide coverage on mortgage securitization pools. 
of the mortgages for which new policies were created during the year. Insurance in force represents the cumulative balance over time of policies written less policies cancelled. The industry Herfindahl index based on insurance written is 1668 .

Figure 1 shows the aggregate growth of the US mortgage insurance industry from 1970. Insurance in force (right axis) shows the industry has grown significantly over the last 30 years, reaching $\$ 750$ billion of mortgage insurance in force by 2003. The new insurance written series (left axis) shows that there have been several significant cyclical swings in insurance sales.

The Figure 1 data can also be used to estimate the average period for which a mortgage insurance policy remains active. In particular, using the data from 1970 to 2004, we estimated:

$$
F_{t}=(1.0) W_{t}+a_{1} F_{t-1}+\varepsilon_{t},
$$

where $F_{t}$ is insurance in force at the end of period $t ; W_{t}$ is new insurance written during period $t$.

The specification assumes that all new insurance written remains in force for the first year. The result, estimated with ordinary least squares 19702003, is (standard error below coefficient):

$$
F_{t}=(1.0) W_{t}+(.74) F_{t-1}+\varepsilon_{t}, \quad R^{2}=.98 .
$$

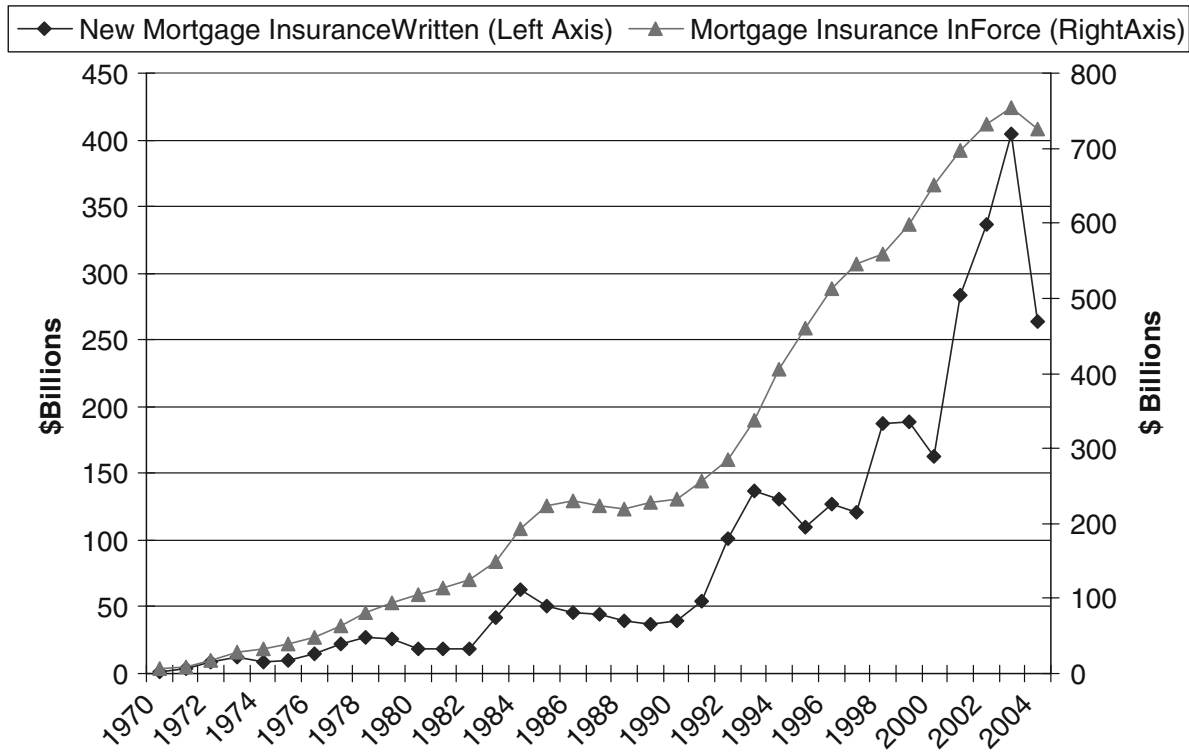

Figure 1. Mortgage insurance in force and new insurance written.

Source: Mortgage Insurance Companies of America and Inside Mortgage Finance. 
The coefficient on lagged insurance in force is .74, which can be transformed to provide an estimate of 2.4 years as the half-life of a mortgage insurance policy, a plausible value. ${ }^{12}$

\section{THE RISKS AND REGULATION OF MORTGAGE INSURANCE}

Figure 2 shows aggregate mortgage insurer loss ratios, defined as annual losses/premiums. The loss ratio rose rapidly during the 1980 s, reaching a peak of close to $200 \%$ in 1987 . Of course, were data available, the loss ratios of the Great Depression would be seen to be even greater. Referring to the loss ratio spikes, Moody's (2003) rating manual describes the industry as a catastrophe line with long tailed loss payouts, while Kau and Keenan (1996) explicitly incorporate catastrophic jumps in their mortgage insurance pricing model. In contrast, the loss ratios for all property and casualty firms, and for title insurance, also shown in Figure 2, are quite stable over time. From 1970 to 2003, the average loss ratio is $49.1 \%$ for

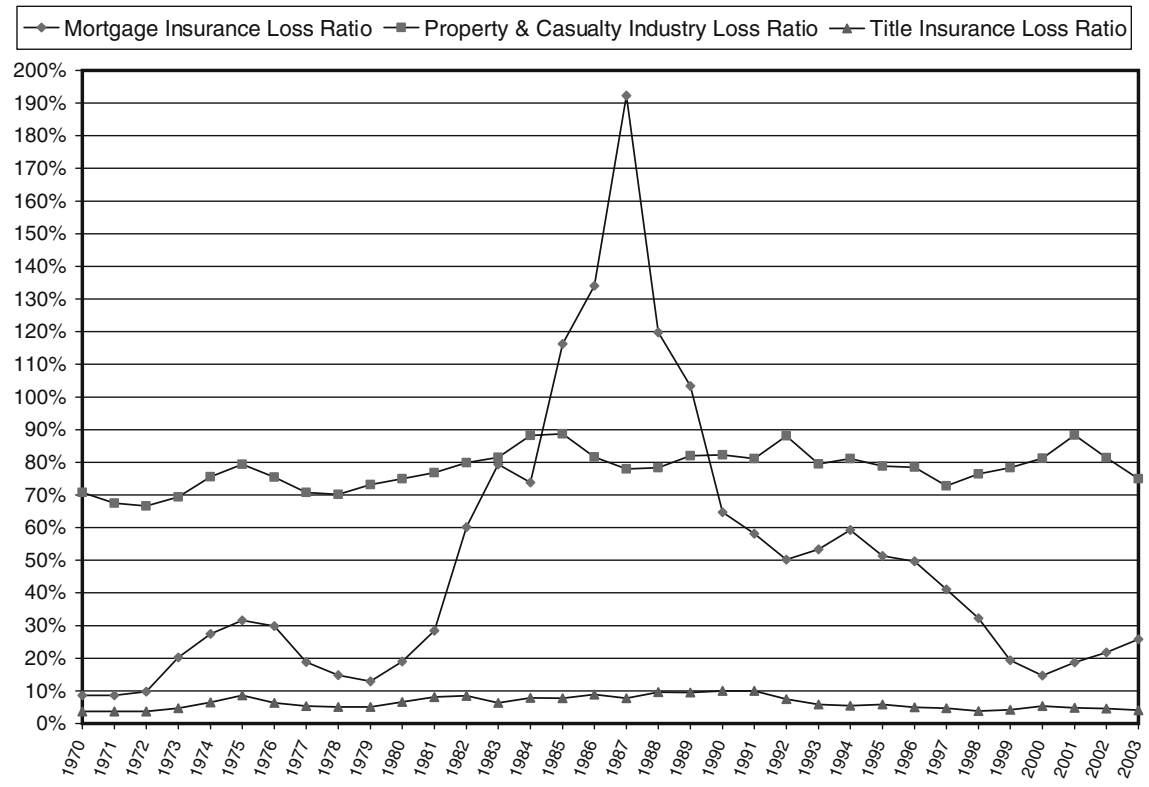

Figure 2. Mortgage, all property \& casualty, and title insurance losses as percent of revenue. Sources: Mortgage Insurance Companies of America, Insurance Information Institute, and Best (2004).

12 This value is, of course, an average over the full period, and it is possible that the half life has actually varied over time, depending on the degree of mortgage refinancing among other factors. However, given the limited number of observations, standard techniques for estimating time-varying coefficients would not converge. 
mortgage insurers, $78.3 \%$ for all casualty insurance lines, and $6.3 \%$ for title insurance (discussed further below).

Falling house prices and rising mortgage interest rates are the precipitating factors for the catastrophic nature of mortgage insurance. House price declines and increasing interest rates tend to affect many properties simultaneously in a geographic region, or possibly the entire country. For example, a major source of the large spike in mortgage insurance losses in the mid to late 1980s was the wave of "oil belt" defaults, from Wyoming to Texas, due to falling oil prices (Kiley, 1986). Other idiosyncratic events also happened at the same time, such as the failure of a major Virginia real estate syndication firm (Equity Programs Investment Corp, or EPIC), which alone accounted for $20 \%$ of the 1985 insurer losses (Kau et al., 1993). This pattern can be contrasted with more traditional lines of casualty insurance, such as auto insurance, where the probability of a large number of cars simultaneously crashing is extremely low.

Mortgage insurers must hold especially large amounts of capital to cover the losses that might aggregate to a very large amount. Raising and maintaining such large amounts of capital creates very special problems for such insurers (Jaffee and Russell, 1997). In fact, other catastrophe lines in the US - specifically earthquake, flood, and hurricane - all now rely on significant government support, as private firms are unwilling to provide the large amounts of required risk capital (Jaffee and Russell, 2003). Similarly, following the terrorist attack of September 11, 2001, most insurance firms became unwilling to continue to offer terrorist insurance, ultimately forcing the US federal government to support the market under the terms of the Terrorist Risk Insurance Act (TRIA) of 2002 (US Treasury, 2005).

Mortgage insurance continues to be provided without government support, but the states regulate the industry in three special ways, reflecting the catastrophic nature of the risks: ${ }^{13}$

(i) A contingency reserve equal to one-half of all premiums received must be maintained for 10 years (unless released to pay claims). This reserve structure is unique to mortgage insurers. ${ }^{14}$

\footnotetext{
${ }^{13}$ California Insurance Code Sections 12640 provides a good example of the detailed regulations adopted for mortgage insurers. Our summary focuses on the three main requirements.

${ }^{14}$ Insurance firms must keep their financial accounts in two different systems, GAAP for public reports and "statutory accounting" for reporting to the state insurance regulators. The two systems differ in a variety of ways, including what are admissible assets, the timing of income accruals, and the like. The contingency reserve appears on statutory balance sheets, but has no GAAP equivalent (in effect, it is included in GAAP shareholder equity). Other catastrophe lines, such as earthquake, hurricane, and terrorist insurance, have no such requirement.
} 
(ii) A 4\% capital ratio applies to risk in force. Risk in force is the insurer's actual risk, not the full mortgage value. For example, if the firm insures the first $20 \%$ of losses on a $\$ 100,000$ mortgage, the risk is $\$ 20,000$. The firm would then need to hold $\$ 800$ of capital for this risk.

(iii) A monoline requirement constrains a firm to write only mortgage insurance and to apply its capital only to claims on that line. ${ }^{15}$ Furthermore, in order to preclude the conflicts of interest that arose during the Great Depression, there are generally also prohibitions against originating mortgages or investing in either mortgages or real estate.

Conditions (i) and (ii) are further clarified in Table II. Line (7) in Table II shows the contingency reserve to premium ratio is 3.7 years. This is shorter than the statutory 10 years stated in condition (i) only because the volume of new premiums has grown rapidly over the last 10 years (as shown in Figure 1). Line (8) in Table II shows the capitalto-risk ratio as of year-end 2003 is $10.1 \%$, far exceeding the $4 \%$ minimum ratio stated in condition (ii). The excess capital is created by two factors. First, the contingency reserve requirement itself creates an effective capital ratio greater than 4\%. Second, Fannie Mae, Freddie Mac, and the rating agencies impose their own "economic capital" requirements on mortgage

Table II. Mortgage insurance industry (Key Data, 2003, \$Millions)

\begin{tabular}{lll}
\hline 1 & Net premiums & $\$ 3385$ \\
2 & Net income (before tax) & $\$ 2160$ \\
3 & Net risk in force & $\$ 152,247$ \\
4 & Policyholder surplus & $\$ 3087$ \\
5 & Contingency reserve & $\$ 12,358$ \\
6 & Total capital $(=5+6)$ & $\$ 15,445$ \\
Ratios & & \\
7 & Contingency to premium $(=5 / 1)$ & 3.7 \\
8 & Capital to risk $(=6 / 3)$ & $10.1 \%$ \\
9 & Return on equity $(=2 / 6)$ & $14.0 \%$ \\
\hline
\end{tabular}

Source: Mortgage Insurance Companies of America (2004).

\footnotetext{
15 In some states, the requirement is only that the mortgage insurance assets, liabilities, and capital be segregated from other insurance lines, but this has the same force as a monoline restriction. For example, California's older mortgage insurance statute 12440 has an explicit monoline restriction, whereas its newer alternative, statute 12640, only specifies the conditions for segregating the activity.
} 
insurers, at levels that generally exceed the legally required "regulatory capital" ratios.

Line (9) in Table II shows the 2003 before-tax return on equity (ROE) earned by the mortgage insurance industry to be $14.0 \%$, which exceeds the ROE of $9.4 \%$ for all casualty insurance lines. Similarly, for the period from 1981 to 2003 , the average ROE for mortgage insurance is $10.5 \%$ compared to $8.8 \%$ for all casualty insurance lines. The higher average ROE for mortgage insurance is not surprising given that its risks are highly correlated with macroeconomic variables, and thus should earn a risk premium based on Capital Asset Pricing Model considerations.

\section{Title Insurance ${ }^{16}$}

Title insurance indemnifies losses created by defective property titles. Title insurance is used by mortgage investors to protect their real estate collateral and by property owners to protect their investment. Title insurers operate under state insurance laws, and most states have imposed a monoline restriction, comparable, but separate, to that imposed on mortgage insurers. Title insurance was created in the United States as early as 1853 by the Law and Property Assurance Society in Pennsylvania. By 1874, Pennsylvania had created the first statutes regulating title insurance. Title insurance expanded during the real estate boom of the 1920s, with policies often provided by the same insurers offering mortgage insurance. These insurers were rendered insolvent during the Great Depression, due to the failure of their mortgage insurance activities.

Title insurance policies sold to property owners are called owner policies; those sold to mortgage lenders are called lender policies. In both cases, a single, up-front, premium is charged, and both policies indemnify the beneficiary against losses created by defective titles. Possible title defects include errors or omissions in deeds, forgery, undisclosed and missing heirs, and undisclosed liens. The title insurer may either pay the legal fees to defend a title and/or provide indemnification for the losses created by defective title. Owner policies remain in effect indefinitely or until the property is sold (continuing protection is afforded heirs to the property), while lender policies remain in force until the associated mortgage is cancelled.

\section{THE US TITLE INSURANCE INDUSTRY ${ }^{17}$}

The title insurance industry consists of both regional firms that operate in specific states and large national holding companies with subsidiaries that

\footnotetext{
16 See American Land Title Association (2005b) for a general industry overview.

17 The title insurance industry's organizational structure is discussed in Boyer and Nyce (2004), Nyce and Boyer (1998), and Lipshutz (1994).
} 
operate in many, if not all, states. Table III lists the national firms and an aggregate for the regional firms and their shares of total premiums written in 2004. There are 44 firms in the industry altogether. The industry's Herfindahl index is 2103 , indicating that it is concentrated and that it is somewhat more so than the mortgage insurance industry (with a Herfindahl index of 1668).

The variations in title insurance revenue over time are very similar to the patterns shown in Figure 1 for mortgage insurers; the correlation for the two series from 1970 to 2003 is $.97 .^{18}$ This is not surprising, since the demand for both derive from the same demand for mortgage loans.

Title insurance is one of the least risky lines of insurance as measured by its loss ratio (= annual losses/premiums), shown previously in Figure 2. Over the period 1970-2003, the title insurer loss ratio averaged $6.3 \%$, compared to $49.1 \%$ for mortgage insurers and to $78.0 \%$ for all property and casualty firms. The title insurance industry maintains such low loss ratios because it insures only risks created by past events allowing the firms to identify and cure most title defects. Title insurers identify title defects by referencing a database, called a title plant, which is a principal asset of the firm. Of course, a title plant may have errors of its own, or an error may

Table III. Title insurance industry (Total premiums 2004)

\begin{tabular}{lcc}
\hline Name & \$ Billion & $\%$ of total \\
\hline Fidelity & 4.7 & 30.5 \\
First American & 4.0 & 25.9 \\
LandAmerica & 2.8 & 18.2 \\
Stewart & 1.7 & 11.2 \\
Old Republic & 0.9 & 6.0 \\
Regional firms (total) & 1.3 & 8.2 \\
Industry total & 15.5 & 100.0 \\
Herfindahl & 2103 & \\
\hline
\end{tabular}

Source: American Land Trust Association (2005a).

${ }_{18}$ There is no series for title insurance in force: although title insurance only remains in force until the property is sold or the mortgage is cancelled, title insurance firms are often not notified that the policy has been cancelled. Without information on cancellations, there is no practical method for computing the amount of coverage that remains in force. 
arise in referencing it; thus claims do occur, but they are relatively infrequent. ${ }^{19}$

The flip side of the low loss ratios for title insurers is that they have exceptionally high operating expense ratios (= operating expenses/premiums). Figure 3 compares the operating expense ratios of title insurers, mortgage insurers, and the overall property and casualty industry. The average expense ratio over the $1975-2003$ period is $92.2 \%$ for the title insurers, compared with $31.2 \%$ for mortgage insurers and $28.1 \%$ for all property and casualty lines. It is apparent that title insurance expense ratios differ in a fundamental way from most other casualty lines, whereas mortgage insurance stands much closer to the standard casualty insurer profile.

\section{THE RISKS AND REGULATION OF TITLE INSURANCE}

With high expenses for identifying title defects ex ante and low realized losses ex post, title insurance is really a service product, and the insurance

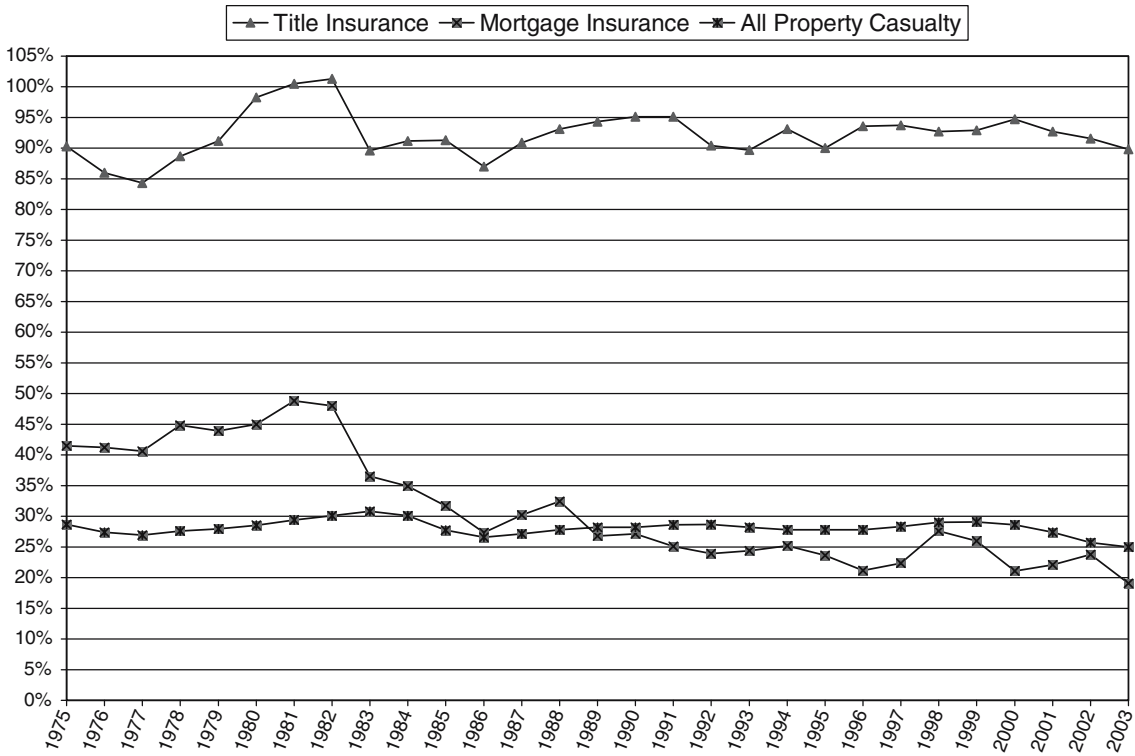

Figure 3. Operating expense ratio (operating expenses/net premiums) for title, mortgage, and all property \& casualty insurers. Sources: Mortgage Insurance Companies of America and Best (2004).

19 Lipshutz (1994) reports that between the Great Depression and the mid 1990s, only two title insurers closed with losses to their policyholders. Also in line with its low-risk nature, title insurance appears to earn relatively low rates of return; for example, Lipshutz (1994) reports for the $1980 \mathrm{~s}$ decade, title insurers averaged an after-tax ROE of $7.2 \%$, compared with $13.4 \%$ for all property/casualty insurers for the same period. 
policy is a form of a product guarantee. Nevertheless, most states regulate title insurance, and it would seem that they do so in large part to enforce a monoline restriction. The California statutes contain the two typical requirements:

(1) A statutory premium reserve equals $4.5 \%$ of gross title insurance premiums. The statutory reserve is released to income on a declining scale, with $10 \%$ annually for years $1-5,9 \%$ annually for years $6-10$, and $0.5 \%$ annually for years $11-20$. The $4.5 \%$ reserve requirement is less than one-tenth of the contingency reserve applied to mortgage insurers (which is $50 \%$ of premiums). The steady release of the title insurance reserve results in a weighted average term of 5.875 years; in contrast, the mortgage insurer reserve is released only after 10 years.

(2) Most states require title insurance to operate on a monoline basis; American Land Trust Association (2005b). The California Insurance Code section 12360, for example, states:

"An insurer which anywhere in the United States transacts any class of insurance other than title insurance is not eligible for the issuance of a certificate of authority to transact title insurance in this State nor for the renewal thereof."

\section{The Monoline Restriction on Mortgage and Title Insurance}

Mortgage and title insurance represent opposite extremes for the risk of insurer insolvency. The catastrophic nature of mortgage insurance creates a significant possibility that insured losses might exceed a firm's resources, creating an insolvency. Title insurance, in contrast, indemnifies only against past events, making large unexpected losses highly unlikely. In this section, we review the arguments, pro and con, as to whether the distinctive features of mortgage and title insurance can reasonably motivate the monoline restrictions that are imposed on both classes of insurers by state laws. We first apply a model from the recently developed insurance literature on the insolvency risk of insurance firms. We then evaluate the implications of this literature in view of the specific institutional and organizational features of the two industries.

\section{MONOLINE RESTRICTIONS IN THE ACADEMIC INSURANCE LITERATURE}

Monoline restrictions have not been directly studied in the academic insurance literature. The insolvency risk of insurance companies, however, has been studied in recent years, using the tools of contingent security and option pricing to value the default option. In particular, Phillips et al. (1998), hereafter PCA, have developed a direct and clear model, albeit only 
in the context of multiline insurance firms. ${ }^{20}$ In this section, we adapt and apply their model to draw specific implications for the monoline issue.

The PCA paper models how the insolvency risk of a multiline insurance company is incorporated into market determined insurance premiums. We separate three classes of assumptions:

(i) The insurance firm deals in two or more insurance lines, possibly with widely varying risks. Its aggregate capital is available and will be applied to pay claims against any of its lines. This is the basic definition of a multiline insurer.

(ii) The policies for all lines are initiated at the same Date 0 , and terminate at the same Date 1. The possible insolvency of the insurance firm is determined at Date 1, with insolvency occurring if the total insurance claims exceed the firm's total assets:

(a) The insolvency condition is based on total claims and assets because a multiline insurance firm cannot segregate its capital to pay losses on only certain lines. Such segmentation, in fact, can be achieved only by a monoline firm.

(b) If the firm is insolvent, then it is assumed that policyholders receive prorated payments based on the ratio of total claims to total assets for the insurer. In particular, the proration will be the same for claims across all insurance lines.

(iii) The multiline insurer operates in competitive, informationally efficient, and complete markets for all risks. These assumptions are needed in order to apply contingent asset and option pricing methods to the problem of valuing the insurance firm's risk of insolvency.

The key result of the PCA model is how premiums are determined for each insurance line $i$ :

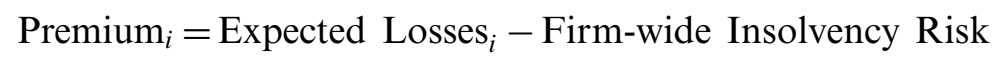

Discount.

Firm Insolvency Risk Discount $=f$ (combined insurance line risks, initial capital).

Equation (1) indicates that line $i$ premiums equal line $i$ expected losses minus the insolvency risk discount. The insolvency risk discount arises

\footnotetext{
${ }^{20}$ The PCA paper also has extensive citations to the previous literature. Furthermore, Myers and Read (2001) provide an analysis of the insolvency risk of insurance firms, in which they propose a method for allocating the capital of a multiline firm across its individual insurance lines for accounting purposes. Myers and Read share with PCA the conclusion that the insolvency risk of a multiline firm is necessarily shared equally across all of its insurance lines, which is the key feature of the models for our current purposes.
} 
because policyholders anticipate that insurer insolvency could create prorated claims payments, thus reducing the premium they are willing to pay. It is a distinctive feature of the model that the insolvency risk discount takes on the same value for all insurance lines, because the policyholders of all lines share proportionately in the costs of any insolvency. Equation (2) indicates that the firm's insolvency risk (a) rises with the combined risk of the insurance lines and (b) falls when the initial capital is greater. The PCA paper applies option pricing methods to derive the specific form of Equations (1) and (2).

A further implication of the complete market assumption and the pricing result is that both the policyholders and the insurer's equity holders are indifferent to how much equity the firm holds. In particular, the insurance premiums on lower capitalized firms will be lower by exactly the amount necessary to compensate the policyholder for the increased risk of insolvency. Similarly, the premiums on higher capitalized firms will be higher by exactly the amount necessary to compensate the equity holders for the higher risk they face. This creates a Modigliani-Miller type indifference to the equity/insurance risk ratio, similar to the traditional Modigliani-Miller indifference to the debt/equity ratio.

\section{A. The PCA Model in a Monoline Setting}

The PCA model analyzes only a multiline insurer and thus does not directly address a monoline restriction. The implications for a monoline restriction, however, can be established with further analysis. One immediate result is that compared to a monoline firm, a multiline insurer receives diversification benefits that serve to reduce its overall insolvency risk. These benefits arise because the multiline insurer's capital is available to pay losses on all lines, thus reducing its overall insolvency risk, while the capital of each equivalent monoline firm may only be used to pay claims on its single insurance line. Thus, there will be loss patterns in which a monoline insurer will be rendered insolvent, whereas it could have survived by accessing the broader capital resources of a multiline firm.

This result is readily demonstrated for the case in which the risks of the individual insurance lines are independent of one another and the expected losses of the individual lines are equal in magnitude. Start by considering a multiline firm serving $N$ different lines and holding initial capital $K$, from which its overall risk of insolvency and the market premiums of the individual lines can be established. Now separate the multiline firm into $N$ separate monoline firms, each of which receives $1 / N$ of the initial capital $K$. The insolvency risk of each of the monoline firms must exceed the insolvency risk of the equivalent multiline firm because unused capital in one monoline firm is not available to pay exceptional losses that arise in another monoline firm. 
A second result of applying the PCA model in a monoline setting, again assuming that the individual insurance lines all have the same level of risk, is that the premiums charged by a multiline firm will be higher than the premiums charged by equivalent monoline firms holding the same aggregate capital. This result follows from the feature of the PCA model whereby insurance premiums equal expected losses minus the discount for the risk of insurer insolvency (Equation (1) above). Since the multiline firm has lower insolvency risk than the comparable set of monoline firms, its premiums will be higher.

The higher premiums charged by the multiline insurer, furthermore, will reflect exactly the amount needed to compensate the multiline equity holders for the greater risk of losing their capital. This conclusion can be clarified with a simple example of a multiline firm with two lines and holding exactly the summed capital of two comparable monoline firms:

$K_{1}=$ capital of monoline 1 ;

$K_{2}=$ capital of monoline 2 ;

$K=K_{1}+K_{2}=$ capital of comparable multiline firm.

Now suppose claims in the amount $X_{1}$ are realized on line 1. There are two cases:

(1) If $X_{1}<K_{1}$, then both the monoline firm 1 and the multiline firm remain solvent, with the equity holder's capital in each of the firms reduced by the same amount $X_{1}$.

(2) If $X_{1}>K_{1}$, then the monoline firm becomes bankrupt, with its equity holders losing their entire stake of $K_{1}$. In the same circumstances, however, the multiline firm will pay at least some claims in excess of $K_{1}$, up to the amount of the additional available capital (namely $K_{2}$ ). Thus, the multiline equity holders will lose an amount greater than $K_{1}$, specifically an amount equal to $\min \left\{X_{1}, K_{1}+K_{2}\right\}$. Given that the equity holders of the multiline firm face a higher risk to their capital, they must be compensated accordingly with a higher premium.

A third result of applying the PCA model in a monoline context arises if the separate insurance lines have extreme risk characteristics, specifically with one line being very safe and the other line being very risky. We can use title insurance and mortgage insurance as cases in point. If a monoline title insurer and a monoline mortgage insurance are combined into a single multiline firm, keeping the aggregate capital equal to the sum of the parts, then the multiline firm's insolvency risk will be a combination of the insolvency risk of the separate monoline firms, with some reduction due to the diversification benefit. With the risks of the two lines at such extremes, almost surely the policyholders of the mortgage insurance line will face a lower insolvency risk at the multiline firm, while the title insurance policy holders will face a higher, indeed a much higher, insolvency risk at the 
multiline firm. ${ }^{21}$ The insurance premiums charged by the multiline firm will appropriately reflect these risks, as discussed above.

A fourth and final result of applying the PCA model to the monoline issue is that, in all cases, the policyholders will be indifferent to whether their insurer takes a monoline or multiline form. This result derives from the PCA assumptions of competitive, informationally efficient, and complete markets (hereafter denoted as the "perfect market" assumptions), which allow the policyholders to adapt to any level of insurer insolvency risk. This is just another aspect of the model's Modigliani-Miller feature, discussed earlier, such that policyholders are indifferent to a firm's insurance liability/equity ratio (which determines its insolvency risk).

\section{MARKET CONDITIONS THAT MOTIVATE MONOLINE RESTRICTIONS FOR TITLE INSURANCE}

We have seen that, taking the assumptions of the PCA model as given the policyholders are indifferent to the choice between a multiline or a monoline structure. In practice, however, multiline insurance firms dominate most insurance markets, the primary exceptions arising when there is an explicit monoline restriction. So it would seem that some factor, not in the PCA model, is tipping the scale toward the multiline format. A good guess might be that economies of scale and scope, factors not considered in the PCA model, are motivating the preference for a multiline format. On the other hand, there may also be specific features of the title and mortgage insurance lines, also not included in the PCA model, that can motivate a preference for a monoline structure. Indeed, it would be consistent with the observed patterns to find some conditions that motivate multiline structures, while there are other conditions that motivate insurance regulators to require a monoline structure. We now start by considering the distinctive features of title insurance that motivate a monoline requirement.

We have already observed that when a monoline title insurer and a monoline mortgage insurer are combined into a single multiline firm, the title insurance policyholders will face a greatly increased risk of insurer insolvency (for which they will be properly compensated with a lower insurance premium). Alternatively, if a group of title insurance policyholders have an especially low tolerance for the insolvency risk of their multiline firm, the complete markets assumption of the PCA model allows these policyholder

${ }^{21}$ In addition to the differing risk attributes, title insurance policies remain in force for a much longer period (on a owner policy, until the home is sold), which further raises the exposure of title policyholders to the risks of insurer insolvency. This factor is not included in the PCA model, because it is assumed that all policies, across all lines, remain in force for the same length of time. 
to sell the increased insolvency risk in a market, and thereby recover the much lower insolvency risk enjoyed at the initial monoline firm.

As a practical matter, of course, these specific risk transfer markets rarely exist. But with a sufficiently large group of such policyholders, a realistic and comparable solution is that a new monoline title insurer would arise to serve their needs. That is, if policyholders largely prefer the risk attributes of a monoline title insurer, then one would expect the capital markets to provide exactly that. Confidence in this outcome, however, requires that title insurance policyholders have sufficient knowledge to make an informed choice, and that there be sufficient ease of entry so that new title insurance firms are readily formed. We now consider these issues.

\section{A. Are Title Insurance Markets Competitive and Informationally Complete?}

The PCA assumptions that markets are competitive and that policyholders are well informed are reasonably satisfied with regard to many insurance markets. For example, for such lines as auto and homeowners insurance, there are many providers in most states, and the consumer is repetitively purchasing a product that is easily compared across firms. ${ }^{22}$ Comparative information can also be readily obtained from similarly placed friends and neighbors. With these conditions in place, it is not surprising that the insurers generally operate on a multiline basis.

The assumption of competition is more questionable in title insurance markets. First, as we saw above in Table III, the title insurance industry has a significant degree of concentration. Second, Boyer and Nyce (2004) argue persuasively that title plants and controlled (or affiliated) business arrangements create significant barriers to entry in title insurance markets. Earlier, White (1984) had noted a significant lack of price competition in title insurance, leading to reverse competition (such as rebates) and controlled business arrangements. As a related matter, there are long-standing accusations of abusive practices in the title insurance market. ${ }^{23}$

The assumption of well-informed consumers is particularly questionable in the market for title insurance owner policies - that is, policies sold to homeowners to protect their investment. These consumers have limited incentive to become well informed because title insurance is purchased only at the time of a home purchase. Home purchase is an infrequent event, and most homeowners would not remember who provided their title insurance.

\footnotetext{
22 Jaffee and Russell (1998b, 2002) discuss the structure of the market for auto insurance.

${ }^{23}$ For example, in Garamendi (2005), the California Department of Insurance announced an agreement for nine major title insurers to pay $\$ 37$ million in refunds and penalties for alleged illegal rebating and kickbacks for the referral of title insurance business.
} 
In addition, the title insurance premium is just one of a long list of closing costs associated with a home purchase, and again most home buyers would be hard put to remember what they paid for it. In fact, the condition of poorly informed consumers in title insurance markets is commonly accepted, and has lead to a variety of laws to protect consumers against abusive practices. ${ }^{24}$

The failure of title insurance markets to be competitive and informationally efficient, together with the low-risk character of title insurance products, can motivate a monoline restriction on owner policies for title insurance. ${ }^{25}$ That is, when insurers combine title insurance with other, higher-risk, insurance lines in a multiline structure, policyholders on title insurance owner policies may be significantly harmed for a number of reasons.

First, informational inefficiency implies that the policyholders may be unaware of the potentially much higher risk of insurer insolvency when their title insurance is offered through a multiline structure. Given the overwhelming importance of the home investment for most American families, it can be expected that most homeowners will have a low tolerance for insurer insolvency risk, even recognizing that lower insolvency risk will require a higher premium. In this setting, it would appear sensible for state legislatures to require title insurers to be monoline firms, thus ensuring that policyholders do not face a significant risk of insurer insolvency. Some states, in fact, further require title insurers to maintain a high degree of care in verifying that no title defects occur. ${ }^{26}$

Second, non-competitive markets and high costs of entry may preclude title insurance policyholders from receiving the lower premiums that would otherwise be warranted if title insurance is provided by higher-risk multiline firms. As noted by Boyer and Nyce (2004), the large fixed costs of creating title plants and establishing affiliated business arrangements are two major factors inhibiting easy entry into the title insurance business.

Third, a lesson remains from the Great Depression experience, in which many title insurers failed because they were combined with mortgage

\footnotetext{
${ }^{24}$ For example, the federal Real Estate Settlement Procedures Act (RESPA) has numerous clauses that attempt to protect consumers against abusive practices that may arise while purchasing title insurance. Similarly, most state laws make title insurance fee rebates illegal, as in California Insurance Code Section 12404.

${ }^{25}$ While lack of competition may in part motivate a monoline condition, a monoline condition is not likely to expand competition. In insurance markets, one of the main regulatory methods for improving competition is for the department of insurance to publish the insurance rates of competing firms.

${ }^{26}$ For example, Section 12 of the Model Title Insurance Act, created by the National Association of Insurance Commissioners, has such a requirement. See Lipshutz (1994), Appendix A, for a copy of the Model Act.
} 
insurers in multiline firms. The incentive to combine title and mortgage insurance apparently continues, since Radian Guaranty, a mortgage insurer, recently tried to introduce a title insurance product. The California insurance commissioner, in Garamendi (2003), however, found the product to be in violation of the state's monoline insurance requirements, forcing the product to be withdrawn from the market.

These arguments support a monoline requirement only for title insurance owner policies, since only the individual property owners are likely to be informationally disadvantaged. Nevertheless, given the large fixed costs of title plants, and the fact that owner policies and lender policies are often based on the same title search, it would appear inefficient to separate the firms, allowing firms that sell lender policies to operate on a multiline basis, while requiring firms that sell owner policies to operate as monoline firms. Furthermore, given the low-risk nature of title insurance, a monoline restriction is unlikely to represent a significant cost even for those purchasing lender policies. Thus a monoline restriction on all title insurance policies appears well motivated to ensure that US homeowners obtain their desired low-risk title insurance.

Although our discussion has focused on title insurance, similar considerations apply to most financial surety and guarantee insurance lines, which sell protection against default risk on bonds, asset-backed securities, and the like. In particular, these lines all operate with high up-front expenditures to enforce a zero-loss underwriting goal, creating very low ex-post claims. It is thus not surprising that most states also require these lines to operate on a monoline basis; see also Standard and Poor's (2002) and Association of Financial Guaranty Insurers (2005). ${ }^{27}$

\section{MARKET CONDITIONS THAT MOTIVATE MONOLINE RESTRICTIONS FOR MORTGAGE INSURANCE}

The failure of competitive and informationally efficient insurance markets can also motivate a monoline restriction on mortgage insurance, but for quite different reasons. The major concern with mortgage insurance is that the catastrophic nature of its risks will be imposed on the policyholders of a safer line without appropriate compensation, or without a means for those policyholders to offset the heightened risk of insurer insolvency. A monoline structure for mortgage insurers eliminates this possible contagion across insurance lines. The specific issues parallel those just discussed for

\footnotetext{
27 Boiler and machinery insurance is another surety line, but it is not typically required to be monoline. A plausible explanation is that the coverage is sold only to commercial clients, and insurance regulation has generally assumed that commercial policyholders can fend for themselves. This coverage may also be more risky than the financial surety lines.
} 
title insurance. It is worth repeating, moreover, that the Great Depression failure of title insurance divisions within multiline mortgage insurers would have been avoided had a monoline requirement been imposed on the mortgage insurers.

In addition to segregating mortgage insurance risks from safer lines, there are two features of a monoline requirement that are likely to benefit the mortgage insurance policyholders directly:

(1) Conflicts of interest are easily constrained with a monoline structure. Specifically, most states prohibit monoline mortgage insurers from investing in mortgage-related assets, while similar restrictions are not imposed on other casualty lines. If mortgage insurers were to operate within multiline firms, then the only sure means to avoid these conflicts would be to prohibit mortgage investments for the entire multiline firm. Given the importance of mortgage investments for most casualty insurers, and the powerful political force of mortgage borrowers, it is unlikely that a general mortgage investment prohibition could be sustained.

(2) A monoline structure allows special contingency reserves to be set aside, which control the risk of mortgage insurer insolvency. In the next section, we discuss why this is likely to be preferred over imposing higher risk-based capital requirements on multiline mortgage insurers.

\section{ALTERNATIVE METHODS OF REGULATION}

In this section, we consider whether superior alternatives to monoline constraints might exist to control the contagion of mortgage insurer risks to safer lines, to limit conflicts of interest from mortgage investments, and to enforce special high capital requirements.

\section{A. Risk-Based Capital Requirements on a Multiline Mortgage Insurer}

In principle, a risk-based capital requirement applied to mortgage insurance risks within a multiline firm can offset the increased risk of insurer insolvency. A simple benchmark, for example, is to require enough additional capital such that the multiline firm's risk of insolvency is unaffected by the addition of the mortgage insurance line. The added capital would have to reduce the stand-alone risk of the mortgage insurer to about the initial level of the multiline insurer, with allowance for the diversification benefit. The policyholders of the mortgage insurance line would then face a large increase in their premiums, since the insolvency risk of their multiline insurer would be much less than that of their previous monoline firm.

The scheme has two drawbacks. First, since existing monoline mortgage insurers maintain much lower capital levels, it would seem that their 
policyholders have a revealed preference for lower premiums and higher insolvency risk. Thus, the mortgage insurance policyholders may not wish to use a multiline mortgage insurer, if this entails the higher premiums that are necessary if the overall risk of the multiline firm is to be unchanged. Of course, monoline mortgage insurers could still arise in such a world, but a monoline requirement is the only sure means to guarantee that there will not be a contagion of risk from mortgage insurers to safer lines within a multiline firm.

The second drawback is that risk-based capital requirements have not worked well since they were promoted by the National Association of Insurance Commissioners in the early 1990s. Cummins (2000) provides an excellent summary of the alternative capital systems, while Cummins et al. (1999) document the very poor performance of risk-based capital standards in predicting and controlling the actual failures of multiline insurers. While these difficulties may be overcome in the future, currently monoline requirements remain the most effective technique for segmenting the risk of mortgage insurance from safer insurance lines.

\section{B. State Mutual Guaranty Plans}

State mutual guaranty plans require the existing firms in certain insurance lines to pay all claims should one firm in their industry become insolvent. These plans thus provide an alternative mechanism to protect policyholders against the risk of insurer insolvency. In practice, the plans operate only for certain consumer insurance lines, such as homeowner, auto, and in some states title insurance, where the risk of insolvency is primarily idiosyncratic to the individual firm. None of the catastrophe lines, including mortgage insurance, are required to participate in such state plans. The reason is that the catastrophe line risks tend to be systematic, in the sense that the same factor is likely to affect all of the firms. Thus, when one of the firms is facing insolvency, the other firms are also likely to face financial distress. In this setting, a requirement to bailout out the policyholders of the first firm may well bankrupt the entire industry. In short, state guaranty plans cannot safeguard policyholders on catastrophe lines.

\section{Earthquake and Hurricane Insurance Operate without Monoline Requirements}

Earthquake and hurricane insurance are provided in the US without monoline requirements, but this is not because they offer an effective means to safeguard policyholders against the risk of insurer insolvency. First, historically these lines were simply not considered to be "catastrophic," until unexpected heavy losses were realized with the 1992 Hurricane Andrew and the 1994 Northridge Earthquake. Previously, the coverage was provided as 
a low-cost rider to the homeowner policy, and given the dominance of large, nation-wide firms in the homeowner market, there simply was no concern for the risk of insurer insolvency. Second, following the two events, most insurers simply stopped providing the coverage, forcing the states of Florida and California to create quasi-public insurers, both of which are monoline. ${ }^{28}$ Subsequently, some new insurers have offered coverage, but they too operate on a monoline basis. The implications are that (i) the coverage is now, in any case, mainly provided through monoline structures, and (ii) it is likely that monoline statutes would be introduced were the risk of insurer insolvency to rise because the catastrophe coverages were again being offered by multiline insurers.

\section{Insurance Holding Companies and Parallels with Glass-Steagall}

We noted earlier that the Glass-Steagall Act, separating commercial and investment banks, was introduced during the Great Depression to stop conflicts of interest similar to those observed at mortgage insurers. Although recent legislation has removed key aspects of the Glass-Steagall Act, this does not offer grounds for similarly removing the mortgage insurer monoline restriction. The chief difference is that the removal of the Glass-Steagall constraint allows only bank holding companies to own both a commercial bank and an investment bank. Individual commercial banks are still prohibited from owning an investment bank, since the FDIC, the bank insurer, is unwilling to cover the much higher risk that would then arise. Comparably, insurance holding companies were never subject to a monoline requirement; they can, and do, own both monoline and multiline subsidiaries. In this sense the recent removal of Glass-Steagall only deregulates banking to the level already enjoyed by insurance. The parallel also remains that just as commercial banks cannot own investment banks, monoline mortgage insurers cannot offer coverage against other insurance lines.

\section{Conclusions}

The paper has developed the economic case for monoline constraints in mortgage and title insurance. For title insurance, the motivation for a monoline structure is that the insurance line is extraordinarily safe, since with careful research a title insurer can eliminate virtually any chance of significant losses due to defective titles. Thus, the major risks for title insurance policyholders arise from the possibility that a multiline insurer

\footnotetext{
${ }^{28}$ See Jaffee and Russell (1997, 1998a) for further discussion of the impact of these events. More recently, prior to September 11, 2001, insurers did not price the terrorism coverage they provided on standard commercial property policies. Then after the attack, they required federal government reinsurance to remain in the market.
} 
could be rendered insolvent due to claims against one of the insurer's other insurance lines. Given the primary role of the home among the assets of most US families, protection against insurer insolvency is likely to be a primary consideration, and given informational imperfections, a monoline constraint can play a beneficial role.

In contrast, for mortgage insurers, the main motivation for a monoline constraint is that, given its catastrophic nature, an extreme wave of mortgage defaults could very well bankrupt these insurers. Thus, if a mortgage insurer is placed within a multiline structure, excess losses on the mortgage insurance line could render the entire firm insolvent, in the fashion of a contagion spreading from one line to another, and ultimately infecting the policyholders of all the firm's lines. A monoline requirement segregates the mortgage insurer risk, as well as providing a useful structure for controlling conflicts of interest and imposing high capital requirements.

Given that a monoline structure is economically desirable, there is a further question as to whether this structure will just arise naturally. If insurance markets are considered competitive and informationally efficient, then there may be no need to impose a legally binding monoline requirement. There are, however, serious questions regarding both of these assumptions. For title insurance, a monoline constraint protects poorly informed policyholders from higher-risk lines. For mortgage insurance, a monoline constraint guarantees that its catastrophic risk will not be unexpectedly imposed on other policyholders within a multiline firm.

\section{Acknowledgements}

I would like to thank the Journal editor and referees, seminar participants at the Wharton School (Pennsylvania) and Haas School (UC Berkeley), and Tom Russell (Santa Clara) for very helpful comments and suggestions. All errors and omissions are mine.

\section{References}

Alger, George, (1934) Report to His Excellency, Herbert H. Lehman, Governor of the State of New York.

American Land Title Association (2005a) '2004 Market Share', available at http://www.alta.org/industry/financial.cfm.

American Land Title Association (2005b) 'Title Insurance: A Comprehensive Overview', available at http://www.alta.org/press/TitleInsuranceOverview.pdf.

Association of Financial Guaranty Insurers. (2005) 'Advantages of the Monoline Structure', available on line at: http://www.afgi.org/monoline.htm.

Best, A. M. (2004) 'Special Report: Title Industry Running on All Cylinders', October 4, 2004, available at http://www.alta.org/industry/AMBest04.pdf.

Boyer, M. Martin, and Charles Nyce (2004) “"Banks as Insurance Referral Agents” Evidence from the Title Insurance Industry', March 2004. 
Cummins, J. David (2000) 'Allocation of Capital in the Insurance Industry', Risk Management and Insurance Review 3, 7-28.

Cummins, J. David, Martin Grace, and Richard Phillips (1999) 'Regulatory Solvency Prediction in Property-Liability Insurance: Risk-Based Capital, Audit Ratios, and Cash Flow Simulation', Journal of Risk and Insurance 66, 417-458.

Danzon, Patricia (1992) 'The McCarran-Ferguson Act: Anticompetitive or Procompetitive?' Regulation 15, 2. Available at: http://www.cato.org/pubs/regulation/reg15n2b.html.

Garamendi, John (2003) 'Garamendi Issues Final Order Prohibiting Sale of Radian Lien Protection Policy', News Release, the California Department of Insurance, July 22, 2003.

Garamendi, John (2005) 'Insurance Commissioner John Garamendi Announcement Major Settlement Agreements with Title Insurers', News Release, the California Department of Insurance, July 20, 2005.

Graaskamp, James (1967) Journal of Risk and Insurance 34(1), 47-67.

Jaffee, Dwight, and Thomas Russell (1997) 'Catastrophe Insurance, Capital Markets, and Uninsurable Risks', Journal of Risk and Insurance 64(2), 205-230.

Jaffee, Dwight, and Thomas Russell (1998a) 'Catastrophe Insurance, Dynamic Premium Strategies and the Market for Capital', in Robert W. Klein, (ed.), Alternative Approaches to Insurance Regulation. National Association of Insurance Commissioners.

Jaffee, Dwight and Thomas Russell (1998b) 'The Causes And Consequences of Rate Regulation in the Auto Insurance Industry', in David Bradford, (ed.), The Economics of Property-Casualty Insurance, National Bureau of Economic Research.

Jaffee, Dwight, and Thomas Russell (2002) 'Regulation of Auto Insurance in California', in J. David Cummins, (ed.), Deregulating Property-Liability Insurance, chapter 5, AEIBrookings Joint Center for Regulatory Studies, pp. 195-236.

Jaffee, Dwight, and Thomas Russell (2003) 'Markets Under Stress: The Case of Extreme Event Insurance', in Richard Arnott, Bruce Greenwald, Ravi Kanbur, and Barry Nalebuff, (ed.), Economics for an Imperfect World: Essays in Honor of Joseph E. Stiglitz. MIT Press.

Kau, James, Donald Keenan, and W. Muller (1993) 'An Option-Based Pricing Model of Private Mortgage Insurance', Journal of Risk and Insurance 60(2), 288-299.

Kau, James and Donald Keenan (1996) 'An Option-Theoretic Model of Catastrophes Applied to Mortgage Insurance', Journal of Risk and Insurance 63(4), 639-656.

Kiley, David (1986) 'PMIs Post First-Time Net Loss, EPIC Blamed', National Thrift News, May 26, 1986.

Lipshutz, Nelson R. (1994) The Regulatory Economics of Title Insurance. Praeger.

Moody's Investors Service s(2003) 'Rating Methodology: Credit Risks of Mortgage Insurers', December 19, 2003, available at: http://www.moodys.com/moodys/cust/research/MDCdocs/20/2002300000425570.pdf.

Mortgage Insurance Companies of America. (2004) '2004-2005 Fact Book', available at http://www.micanews.com/press/factsheets.cfm.

Myers, Stewart, and James Read (2001) 'Capital Allocation in Insurance Companies', Journal of Risk and Insurance 68(4), 545-580.

Nyce, Charles, and M. Martin Boyer (1998) 'An Analysis of the Title Insurance Industry', Journal of Insurance Regulation 17(2), 213-242.

Phillips, Richard, David Cummins, and Franklin Allen (1998) 'The Financial Pricing of Insurance the Multiple-Line Insurance Company', Journal of Risk and Insurance 65, 597-636.

Rapkin, Chester (1973) The Private Insurance of Home Mortgages. Revised Edition.

Standard and Poor's (2002) 'Bond Insurance Overview and Analytical Focus', May 28, 2002, available on line at: http://www.afgi.org/pdfs/sp\%20overview\%200502.pdf. 
US Department of the Treasury (2005) 'Assessment: The Terrorism Risk Insurance Act of 2002', June 30, 2005.

White, Lawrence (1984) 'The Title Insurance Industry, Reverse Competition, and Controlled Business', The Journal of Risk and Insurance 51, 308-319. 